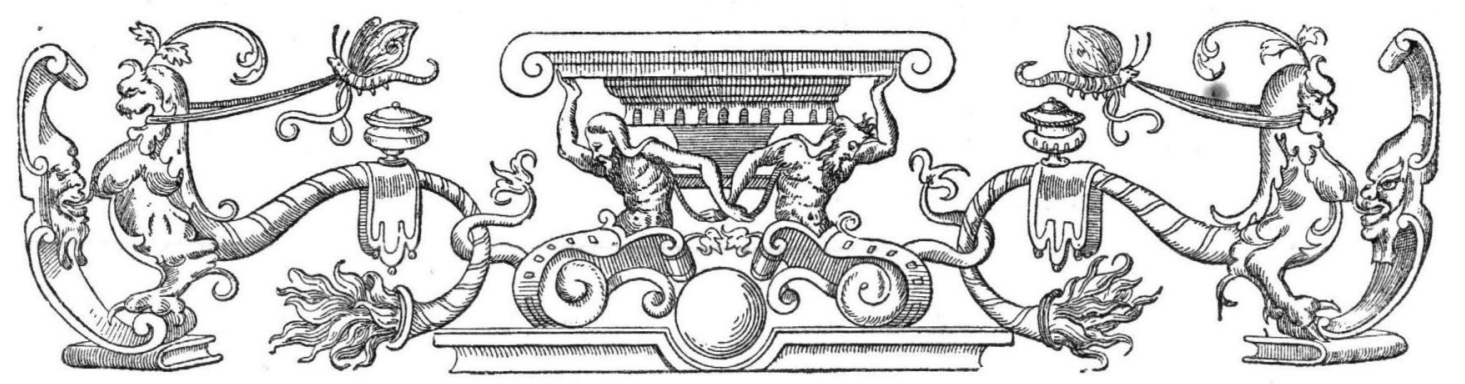

\title{
DE ONZE LIEVE VROUWE TOREN
}

\section{TE AMERSFOORT,}

\author{
DOOR
}

W. F. N. VAN ROOTSELAAR.

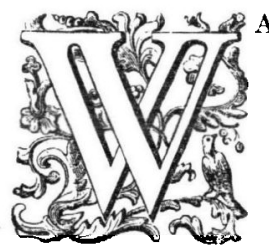

AARSCHIJNLIK heeft men in I445 met den bouw van den toren een aanvang gemaakt. Aanleiding daartoe gaf de volgende omstandigheid, die door de geschiedschrijvers van dien tijd, als ontwijfelbaar zeker, wordt medegedeeld.

In 1444, omstreeks Kersmis, begaf zich een jonge dochter uit $\mathrm{Nij-}$ kerk, GEerTGEN ARENDS geheeten, naar Amersfoort, om aldaar in het Sint-AgnietenKlooster te worden opgenomen. Zij had o. a. bij zich een klein "simpel Beeldeken van "ons L. Vrouwen", dat er tamelijk onooglijk uitzag. Bij de Kamppoort te Amersfoort gekomen, dacht zij bij zich zelven "dattet schande was" om "soodanig Beeldeken in 't "Klooster te brengen, en de susteren te laten sien. Ende met onbedagtsaamheyd wierp „sij 't selve Beeldeken in de waterbeek", d. i. in de buitengracht, voor dat zij in de Poort kwam. Omstreeks denzelfden tijd, werd een eerbare vrouw, MARGRIETE Albert GIJSEN genaamd, "in den droom tot driemaalen vermaand", om buiten de poort van de stad, uit de gracht, waar het water bevrozen was, een beeldje van Onze Lieve Vrouw te gaan halen. Toen zij voor een derden keer in den droom daartoe vermaand werd, stond MARGRIETE op, begaf zich buiten de poort, en vond daar in de buitengracht, juist zoo 
als haar in den droom gezegd was, het beeldje onder het ijs. Het water stroomde onder het ijs voor:-, maar het beeldje bleef stil liggen. MARGRIETE nam het beeldje mede naar huis, stak er een kaars bij aan, en toen deze drie malen langer dan gewoonlijk brandde, kon zij niet langer verzwijgen, wat haar overkomen was. $\mathrm{Zij}$ deelde haar zonderling wedervaren mede aan JAN VAN SchoONHOVEx, een pater Carmeliet, die haar biechtvader was en "onse Vrouwe broeder" geheeten wordt. Er bestond namelijk te Amersfoort een kapel of kerk, gebouwd ter eere van de Moeder des Heeren, welke kerk door een vereeniging van twasif personen bestuurd werd. Reeds in I390 is or spraak van een Broederschap van Deekens, Procuratoirs en gemens Broeders van onzer Vrouzue Capelle, siande in onser Vrouve Kerke t'Amersfoort, ende Kerkmeesters der Kerke van onser Liever Vrourve voorscheven. Puter JAN VAN Schoonhoven, die zeer zeker in nauwe betrekking tot die Kapel en Broederschap gestaan heeft, nam het beeldje mede naar huis, en zie, ook daar, in zijn eigen woning hadden er in het bijzijn van dat beeldje wonderbare gebeurtenissen plants, die op buitengewone wijze de aandacht trokken. Ten gevolge daarvan werd besloten, om het beeldje naar een meer waardige en passende plaats over te brengen. Zulks geschiedde op St. Stephanus-dag, 1444. De geschiedschrijver verhaalt, dat het beeldje, "met alle eerweerdigheidt in de Kurke van Onze L. Vrouwe gebracht" werd. Ock in dic kerk trokken talrijke voorvallen, die bij dat beeldje geschiedden en geheel buitengewoon waren, aller aandacht. Spocdig kwamen een groot aantal personcn uit verschillende plaatsen toegesneld, om voor het beeldje van Onze Lieve Vrouwe aan God gunsten te vragen, of Hem voor ontvangen genaden te danken. In cen Heidschrifi in $4^{\circ}$, Archief van de Kerk van O. L. V. Hemelvaart te Amersfoort, vindt men meer dan 440 voorbeelden opgetcekend van personen, die hun genezing, of bevrijding uit de gevangenis, vooral hun redding bij storm op zee, aan de voorspraak en het gebed van Onze Lieve Vrouw van Amersfoort toeschreven. Spoedig, reeds in I446, werd besloten, om jaarlijks op Zondag voor Pinksteren, het beeldje, in plechtigen optocht, rond te dragen. Vrijgeleide werd dan gegeven. Zulks duurde tot Pinksteravond. De geheele stad vierde feest. Van heinde en ver kwamen duizenden en duizenden toegestroomd, om aan den optocht, die verscheiden uren duurde, deel te nemen. Door de offeranden der vele pelgrims die, uit dankbaarheid voor een verkregen gunst, of wel, om van God een gunst te verkrijgen, groote geschenken gaven, werden aanzienlijke sommen bijeengebracht. Met behulp van die gelden werd, ter vereeuwiging en verheerlijking van het wonderbare feit, "de Kerk vergroot en de heerlijke Toren gebouwd." Ook werden eenige hoeven lands gekocht.

In het Sted. Archief vindt men omtrent het bouwen van den Toren geen enkele bizonderheid. Het Archief der I. V. Kapel is, òf vernietigd, of in I 579 vermoedelijk naar Brussel, misschien naar Keulen, overgebracht. Van daar, dat met zekerheid niets bekend is van den naam van den bouwmeester, of van het jaar waarin de bouw begonnen, 
of het jaar, waarin de bouw geëindigd is. Niets bestaat er van plannen of teekeningen. De eenige bijzonderheid, die men vindt opgeteekend, bestaat in een waarschuwing, door den Raad of de Magistraat in I47 I tot de burgerij gericht.

Die waarschuwing luidt als volgt:

„Die Raedt laet weten dat een ygelike sijn kinderen en hem selven huede en waere, ,also men op ons vrouwen toren metselen sal, dat sij daar nyt of beschediget of gequeest „en werden, want die rait en sell dair geen richtynge van doen." Twee zaken schijnen met zekerheid hieruit te kunnen worden afgeleid: $I^{\circ}$. in het jaar I47I was de toren nog niet voltooid; $2^{\circ}$. de bouw schijnt een tijdlang onderbroken te zijn geweest. Zou men uit die uitdrukkelijke waarschuwing ook niet mogen besluiten, dat er vroeger ongelukken hadden plaats gehad, en dat de Raad, ten gevolge der moeilijkheden, die daaruit ontstaan waren, besloten had in het vervolg "daer geen richtijnge van te doen." In het jaar 1579 ging de O. L. V. Kapel, die met den Toren een geheel uitmaakte, over in handen van de Protestanten. De Broederschap, die tot dusverre het bestuur van de Kapel en den toren in handen had gehad, hield op te bestaan, en in plaats daarvan werd een Boekhouder en twee Adjuncten aangesteld. Zulks duurde tot 1634, I4 April, toen, in navolging van de voormalige Broederschap, een Collegie van twaalf personen werd opgericht, van hetwelk jaarlijks twee leden, een tot Rentmeester, en een ander tot Dispensier, benevens twee anderen, tot Adjuncten werden benoemd, $Z_{\mathrm{ij}}$ hadden vooral voor de finantiën van Kapel en Toren te zorgen. De Magistraat der stad had de opperste leiding der zaken in handen genomen.

In Nov. 1787 was, ten gevolge der tijdsomstandigheden de O. L. V. kapel niet alléén tot een verzamelplaats van ammunitie, maar ook tot een soort van laboratorium verlaagd, waar bommen schoongemaakt, gevuld en verder afgewerkt werden. Een der soldaten beging de onvoorzichtigheid met een mes den roest van een bom te schrappen. In het nabijliggend kruid vloog een vonk, en cell vreeslijke ontploffing volgde. Het gewelf stortte in en overdekte zeer gelukkig een voorraad van ruim I6o vaten buskruid, die daar met onvergeeflijke onvoorzichtigheid, in het midden van de stad, opeengestapeld lagen. Zeventien menschen verloren het leven, anderen werden geblakerd en gekwetst. Ook de kanonnier, die de oorzaak was van het onheil, moest zijn onbedachtzaamheid met zijn leven betalen. De toren, die door een breede straat van de kerk gescheiden en slechts door middel van een boog over de straat, verbonden was met de kerk, had door het ongeval niets geleden. In het begin van deze eeuw werd de kerk voor afbraak verkocht. Nog bleef hetzelfde College of Bestuur voortbestaan, totdat in 1838 de goederen van de voormalige L. V. Kapel en Toren, publiek verkocht zijn, en de opbrengst tusschen de stad en St. Joris-kerk gedeeld werd.

Toen eenmaal het besluit genomen was, dat er ter vereeuwiging van den St. Stephanus-dag, I444, een hooge toren zou gebouwd worden, kwam men spoedig op het denkbeeld 
om aan den toren, zooveel mogelijk, de vormen van het gevonden beeldje te geven. Eenstemmig is de getuigenis van het nageslacht, dat die gedachte op voortreffelijke wijze is uitgevoerd. Ziehier wat $v$. Bemm. I, I 42, daaromtrent getuigt: „Bij deze Kerk staat "een schoone, hooge Toren, mede de $L$. Vrouwe Tooren genoemd en in verbeelding van ,deselfden $L$. Vrozuze gebouwdt, want men de trap tusschen de tweede en derde omme,gang met die intentie buiten het muurwerk gemetselt ziet, met een klein spits daar „op, om daardoor een kind te vertoonen, wijl men dusdanig die Maget af beeld.” Treffend zijn de bewoordingen, waarin J. CRAANDIJK, Predik. bij Doopsg. gem. te Rotterdam. Wandel. door Nederl. I875, bldz. 324, hetzelfde erkent: ,het omwonend landvolk begroette ,in het statig gevaarte het beeld der Gezegende onder de vrouwen, en vooral als de "schemering de vormen wat omsluierde, als de verre afstand de détails in een' nevel "hulde, dan zag hun oog de statige gestalte der gebenedijde Moeder des Heeren miet haar ,goddelijk kind op den arm, die beschermend en zegenend te midden van het uitge„strekte landschap stond, en de geloovigen tot dankbare aanbidding (van het kind Jesus) "en vertrouwelijke vereering noodigde." Op eenigen afstand vóóral, beantwoorden de "grootere lijnen van den toren geheel en al aan den vorm van een beeld van Maria, met het kind Jesus op den arm. Het kindje wordt voorgesteld door een torentje, dat tusschen den tweeden en derden omgang buiten het murwerk van den toren, als afzonderlijk geheel, werd aangebracht. Zoo gelukkig is de kunstenaar geslaagd, dat het torentje nog heden door het volk ,het Kindje" geheeten wordt. Die bouwmeester was een groot kunstenaar. Inderdaad, alleen een kunstenaar van groote talenten kan het geweest zijn, die een dergelijk geheel oprichtte, zonder dat daardoor een misstand veroorzaakt werd. Niet alleen is er van een misstand in het geheel geen spraak, maar het "Kindje” vormt een karakteristiek sieraad van dezen toren, terecht Lieve Vrouwe Toren geheeten, Rank en slank, fier en stout, sober van lijnen en rijk van vormen, rijst de O. L. V. toren ten hemel. Op verren afstand zichtbaar overheerscht hij het geheele Eemdal, en trekt hij, sints meer dan vier eeuwen, de oogen van alle geslachten tot zich, als stond hij daar sints den dag van gisteren, en werd hij voor den eersten keer aanschouwd. Men behoeft waarlijk geen profeet te zijn, om te voorspellen, dat ook de verste nakomelingschap, als met godsdienstigen eerbied, tot den monumentalen bouw zal opzien.

De overlevering zegt ons, dat de kunstenaar, die te Antwerpen en te Rhenen den toren bouwde, ook hier ter stede werkzaam zou zijn geweest. Volgens Dr. LuBkE, Geschiedenis der Architectuur, is JoAnnes Amelus, uit Boulogne, bouwmeester van den toren te Antwerpen geweest.

De toren staat gebouwd op een stuk grond, tegenover de Kapel gelegen, op dezelfde plaats, waar de oude stadsmuur gevonden werd. Kapel en Toren waren van elkander gescheiden door een breede straat. Om beiden aan of met elkander te verbinden, was er over de straat een spitsboog gebouwd, die den doorgang vrijliet. Nog heden zijn op den toren de lijnen van dien boog zichtbaar. Aan de tegenovergestelde zijde grenst het 
terrein aan den binnensingel, een gracht, die vroeger rondom de stad gevloeid heeft, maar die in lateren tijd door de buitenstad werd ingesloten. De toren, in N. Oostelijke richting, heeft van den beganen grond in het Westerfront, een hoogte van M. 94,50. Bij den ingang, aan de N.O. zijde, bedraagt die hoogte, gemeten van de straat:

$$
\begin{aligned}
& \text { Eerste omloop . . . M. 31,60 }
\end{aligned}
$$

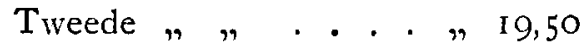

$$
\begin{aligned}
& \text { Derde } ", \quad . . . \quad \text { 19,60 }{ }^{1} \text { ) } \\
& \text { Spits . . . . . } \frac{n 22,20}{\text { M. } 92,90}
\end{aligned}
$$

Volgens v. Bemm. I, r46, heeft de tweede omloop een hoogte van voet. 72 , en de derde omloop een hoogte van voet. 70 , hetweik met bovenstaande opmeting een verschil oplevert van niet minder dan M. 1,60. In de opgave van de hoogte van de spits bestaat een nog grooter verschil. Bij $v$. Bemm. I, I 46, leest men, dat hij de nette voetmaat heeft opgenomen. Wie twijfelt er aan? In cen Handschrift van het Sted. Arch. treft men de opmeting aan, door Lenart NiCAsius, $A^{\circ}$. 1656, gedaan. NiCAsius heeft in 1655 de spits gebouwd, zoodat hij volmaakt op de hoogte was van de verschillende afmetingen. Uiterst toevallig komt de opgave van V. BEMM. in 1760 , het jaar, dat hij zijn Beschrijuing heeft uitgegeven, geheel en al overeen met die van NICAsius in 1656. Ziehier beider opgave:

Van den 3den omgang tot de loode zolders . . . Voet. I7-

Van daar tot de voet van den kruk. . . . . . " $12-4 \mathrm{~d}$.

De voet onder den kruk . . . . . . . . . . " " $10-3$

De kruk hoog . . . . . . . . . . . . . " $13-8$

De lantaarn . . . . . . . . . . . . . ., $10-$

De voet boven den lantaarn . . . . . . . . . $"$. 6 -

De kroon of peer . . . . . . . . . . . . . . " . $16-$

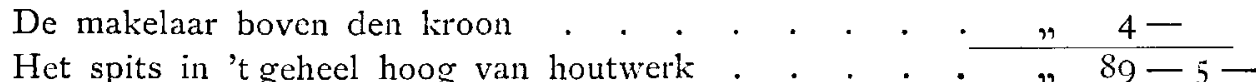

Het kruis met den haan is samen hoog boven den makelaar $\frac{" 12-}{\text { "10I- }-}$

In onzen tijd bedraagt de hoogte van de spits, gelijk reeds gezegd is, niet meer dan M. $22-50=$ Voet. 77,75. Er bestaat dus een verschil van niet minder dan M. 7 of voet. 24. De lantaarn, hoog ro voet. en de voet boven den lantaarn, hoog 6 voet., nog aanwezig in 1760 , toen v. BEMMEL zijn Beschrijuing uitgaf, zijn dus in lateren tijd weggenomen. Ook is het duidelijk, dat tegenwoordig de kroon of peer geen hoogte heeft

1) $\mathrm{Na}$ nieuwe, zeer nauwkeurige opmeting door den Heer W. H. KAM, Stads-Architect en Leeraár aan de H. B. school. In Amersfoort, 777- I580, staat opgegeven M. I9,20.

2) De drie omloopen zijn door fijnbewerkte steenen balnstraden zoodanig afgezet, dat er zonder de minste vrees voor eenig gevaar overvloedige ruimte bestaat, om van alle de kanten de heerlijkste vergezichten te genieten. 
van 16 voeten $=$ M. 4,50. Men heeft dus na 1760 de spits ingekort, maar, helaas, niet fraaier gemaakt. Een bespottelijk figuur is het hakmes, dat boven op het kruis den traditioneelen haan vervangen heeft.

Ten gevolge van den afhellenden grond naar het Westen, bestaat er, tusschen de hoogte van het Westerfront en het Noord-Oosten, een verschil in hoogte van M. I,60 Onder den beganen grond bevindt zich een vrij ruim gewelf of kelder, waarin tot zelfs in onzen tijd, personen, die zich aan kleinere overtredingen hadden plichtig gemaakt, voorloopig in bewaring werden gebracht. Reeds in 1528 , leest men, dat die kelder tot datzelfde doeleinde werd gebezigd. Eenige Geldersche krijgsgevangenen, aan wien aldaar in dat jaar een verblijf was aangewezen, wisten te ontsnappen. Van den beganen grond in het $\mathrm{N}$. Oosten heeft de voet van den toren een breedte van M. I I,80. De eerste en tweede omloop vormen elk een langwerpigen vierhoek. De derde omloop is achtkantig, terwijl het kleine torentje (het kindje) vijfkantig is.

Rijkversierde steunbeeren in laat-gothischen stijl staan aan de hoeken. Nissen met maaswerk versieren dit gedeelte, dat in bak- en bergsteen is opgetrokken en van boven door een balustrade wordt afgesloten. Vooral tusschen die balustrade en het tweede gedeelte van den bouw is langs de vier zijden genoegzame ruimte, om zich ongehinderd te bewegen, en het prachtig panorama, dat de schilderachtige omgeving oplevert, te bewonderen. Het achtkant op den derden omloop is geheel van bergsteen en zeer doorluchtig gebouwd; iedere zijde is met maaswerk gevuld en door wimbergen gekroond. In dit gedeelte wordt het fraai klokkenspel gevonden, waarvan de meeste klokken door den beroemden HEMONY gegoten zijn. Áan de oostzijde bevindt zich de traptoren ,het kindje” geheeten.

De spits van den toren heeft in den loop der tijden veel te verduren gehad. In I 547, op Vitalis-avond, 27 April, sloeg de bliksem in den toren, waardoor,,de cap" geheel en al verbrandde. Het geliet, of als de stadt verbrandt soude hebben door de swaeren bliksem. Er werden herstellingen aangebracht, maar deze werden zoo onvoldoende uitgevoerd, - MAARTEN VAN ROSSUM had kort te voren de stad geheel leeggeplunderd, er zullen dus geen genoegzame geldmiddelen aanwezig geweest zijn, om de restauratie naar behooren te doen plaats hebben, - dat reeds spoedig daarna, in $155^{8}$, de spits door den wind werd nedergeworpen. Van de restauratie, die toen plaats had, is, bij gebrek aan bescheiden, niets te melden.

In 1623,9 Febr., werd de toren op nieuw door den bliksem getroffen. Kruis en weerhaan werden afgeworpen en een gedeelte van de spits vernield. In het Handschrift vań het Sted. Arch. leest men, dat zulks plaats had op den 30 sten Januari. Op dien dag ,syn met een onweder drye vreeselyke donderslaegen nae malkanderen gegaen, en , is den brand boven in den L. Vrouwen Toren geraeckt, sonder dat men het wiste, voor , omtrent ten thyen uyren voor de noen, soo alsdoen het kruys en den weerhaen van „boven nedervielen en heeft den geheelen dagh voorts het houten werck boven in den 
Toorn gesmeult, en is eindelijk gelescht sonder meerder schade te doen." Waarschijnlijk heeft het weder eenige jaren geduurd, eer men tot restauratie overging.

In 1651,7 Febr, had de toren het op nieuw hard te verantwoorden. De bliksem trof de spits, waardoor dese tot over de veertig voeten afbrandde, en aan het overig gedeelte van den toren groote schade aanrichtte, "'t welk een deerlijke en schrikbarende ,vertooning voor de stad was." In het reeds vermelde handschrift, aanwezig in het Sted. Archief, lezen wij daaromtrent het volgende:

„Den 7 den Februari, des voernoens even nae thyen uyren, heeft de plaegende en ,opgeheven handt van Godt door wyndt, sneeuw, donder en blixem het spits van L. "Vrouwen toorn geraeckt en in brandt gestoocken, omme welcken brandt te slissen „LENERT NiCASIUS, timmerman, goede plichten heeft gedaen, klimmende door het luyk ,van bovenste loodesolder uyt, allwaer hij rondom van de brandende styllen omcingelt ,stondt, sulx dat syn klederen van syn lyf verbranden en seer vant smeltende lood als "met sneeuw bedropen wierdt, doch echter heeft door Godts goedheyt den brandt vorder gesteuijt." NiCASIUS kreeg den 24sten Februari, 165I, tot recompensie, boven een vereering van 50 Car. guld, cen nieuw kleed, benevens een lyfpensioen insgelijks van vijftig Car. guld., in te gaen den 7 den Febr. $165 \mathrm{I}$. Reeds in 1658,4 Jan. wordt vermeld, dat hij overleden was. Op het Raadhuis, in de kamer van den Burgemeester, hangt het portret van LEONARD NICASIUS, geschilderd door de meesterhand van onzen stadgenoot, JACOB VAN CAMPEN, den bouwmeester van 't achtste wonder. Onder het portret leest men de volgende dichtregelen:

NiCASIUs alto pectus inflatus Deo
Ignes Olympi perdomat forti manu,
Urbi salutem, gloriam quaerens sibi
Hunc arte pingens CaMpIUs coelo sacrat. 1)
De toren Godts ontstack dees toren
Doch Godt Leent 't hert (opdat verloren
Niet gaen) NiCAES, die blust de vlam.
Hem loff, dies 't beeldt van CAMPEN quam.

Den 7 February, I 651 .

Vrijdaghs omtrent half elf

des morgens.

Het duurde geruimen tijd, eer men het besluit nam wederom een spits op den toren te plaatsen. De herbouw was een groot en moeilijk werk, dat vele uitgaven vorderde, en, nog meer dan tegenwoordig, scheen men het spreekwoord: Festina lente, in toepassing te brengen. Eerst in 1654 vindt men van restauratie melding gemaakt.

In het Resolutieb. 1654, 2 I Aug., vindt men daaromtrent het volgende opgeteekend. De Heeren Burgemeesteren en Oud-Burgemeesteren waren met de Heeren Regenten van

1) De vertaling van het latijnsche onderschrift luidt als volgt: Door hooge geestdrift vervoerd, bedwingt Nicasius met krachtige hand het hemelvuur. 'Ten dienste der stad, tot eigen glorie schenkt van CAMPEN hem op 't paneel de onsterfelijkheid. 
de Kapel in overleg getreden, om met hen te beraadslagen over de wijze, waarop de "Toren van voorzeide Kercken weder opgebouwt soude kunnen worden." In het rapport, dat zij daaromtrent aan de Magistraat mededeelden, verklaarden zij met verscheiden meesters en werkbazen, zoo van Amsterdam, Arnhem, als deze stad, in conferentie te zijn geweest. Verschillende modellen tot dien einde hadden zij geëxamineerd. Door eenige timmerluyden alhier was "seecker modell beraemt ende opgegeven, $t$ 'welck in den Raad "wederom gevisiteert" werd. Nogmaals werden de voorseide timmerluyden daerop gehoort, "totdat eindelijk door gemelte Regeerders wert verstaen en geresolveert, dat conform „t'voorseide lcste model den voorseide toorn wederom sall worden opgebouwt."

In het Handschrift van het St. Arch. leest men dat, "dit spits in den jaere 1655 ,in de somer wederom opgebouwt door LENERT NICASIUS voornoemt en NICASIUS sijn „soon, die het steygerwerck daer toe noodich voor ses hondert guld. hebben aengenomen, „boven yder een Roosenobel tot een vereeringe, maeckende het vorder werck bij dachhuyr, "welverstaende, dat sij tot het voorsegde steygeren all het hout, ijser en touwen op haer "Costen mosten leveren en mosten 't oock weder aff breecken."

Op dezelfde uiterst voorzichtige wijze werd gehandeld, eer de Raed er toe oversing, om de spits met koper in de plaats van lood te bekleeden. In het Resolutieb., I655, I 7 April, leest men daaromtrent de volgende bizonderheden, die van belang genoeg zijn, om bcknopt te worden medegedceld. De Borgemeesteren en Oud-Borgemeesteren waren over de zaak in conferentie geweest met de Regenten van de Capelle, en brachten verslag uit van het verhandelde aan den Raad. Herhaaldelijk waren zij te zamen geweest, om te beslissen „off t'nieuw te makene spits van deselve Kcrckx Toorn beclcedt ofte bedeckt "soude worden, met loot ofte met kooper". Zij hadden daaromtrent de advyzen ingewonnen van de "Heere JaCob VAN CAMPEN, Mr. JAN Wijbrantsen, woonende tot Amsterdam, (JohAN WijBRANTZEN CoLCK, Resoluticb. 1655, 7 Mei), mitsgaders verscheyden Cooperslagers binnen dese stad, alsmede de leydeckers.

Eindelijk was op den ...? Martij voorleden, na langdurige deliberatie en onderzoek besloten dat "de Cooperslagers en leydeckers yder een schinckel van de Peer tot een "proeve souden becleden met cooper en loodt respective $t$ ' welck doenmaals geoordeeld "wierdt het swaerste en difficylste werck te wesen, oock sulcx, dat hetselve werck, bequa"melick kunnende worden becleet met cooper, oock alle het vordere werck insgelijks "bequamelick met cooper soude kunnen worden becleet". De proeven werden genomen, en door de Gecommitteerden (van den Raad), en de Regenten onderzocht. Op den I6den dezer waren genoemde Hecren weder ,in conferentie gecomen'. Wederom was gehoord het advies van "Heere VAN CAMPEN en voorighe werckbasen". Er was van hen vernomen, dat ,het cooperwerk den toorn merckelick soude verlichten, ende oock veel durabelder "wert geoordeelt als het loodt, t' welck gehouden wort door de locht, cou ende windt "te worden geconsumeert ende dienvolgende meer opsicht, costelijcker reparatie ende "onderhout van nooden te hebben", enz. Op approbatie van de Regeerders hebben 
gevolgelijk de "Regenten van selve Capelle geresolveert om all het voorseide werck voor "sooveel doenlick en mogelick is met coper te bedekken en te becleeden". Alvorens echter daartoe over te gaan ,sullen de cooperslagers, soo haest doenlick, hebben te be„cleden t'onderste vant nieuwe werck en van daer een stijl opgaende, met sijn onderste "en bovenste carbeelen tot aen de tweede lijste incluys". De koperslagers werden daarop in den Raad ontboden, en hebben waarschijnlijk op zich genomen het werk in dier voege uit te voeren. Er werd althans besloten, dat de bekleeding van de spits met koper zal plaats hebben. - In bovengemeld handschrift leest men daaromtrent: „de Regenten van ,de L. Vrouwen Cappelle, met assumtie van de Borgemeesteren en oudt-Borgemeesteren, „op den 30sten May, I655, vergadert sijnde, hebben, allvoorens oculaire inspectie van „een proefie van cooperslaghers op den toorn genomen hebbende, eenpaerich goedge"vonden, het nieuwe gemaeckte spits met deckplaten van kooper in plaetse van loodt te „bekleeden, waerop sij voorts door haer Gecommitteerdens, DOMSELAER en BRONCHORST, ,int bijsijn van een kooperslagher JOOST JANSEN BAECKEN, kooper, daertoe noodich, tot "Amsterdam hebben gedaen koopen, omme het selfde alsoo te volbrengen."

Het volgende Chronicon werd daarop gemaakt:

Het Cooper noIt Vergae Vant spIts soo braef geMaeCkt, ' $\mathrm{k}$ Wensch U geen tIIt Verteer, noCh Wint, noCh Vueren raeCkt.

Benevens de volgende wensch:

Faxit deus, ut hoc monumentum sit aere perennius. Geve God, dat dit monument langer dan het koper besta.

Het handschrift vervolgt in dezer voege: Het Cruys van (den) Toorn is gemaeckt tot Amsterdam bij Willem Hermansz vaN Till, weegende 750 ponden, sonder veeren, te samen, ycler pont is aenbestaedt voor twaelff sts: daer onze amersfoortsche smits het pond hadden verlaeten voor I 8 sts. In margine: yder pondt kooper gekoft tot I4 sts., en bescheyden yder pondt van snipperingh te moeten aennemen voor lo sts.

't Voorseide Cruys mette spil sonder de veeren is hoogh II la voeten, breed 8 voeten, de veeren sijn langh 5 voeten, de spill is int geheel lang 23 duym en schiet 5 duym int lichaam van den haen; desen haen is langh $4 \frac{1}{4}$ voeten, hoogte $3 \frac{1}{2}$ voeten en breed 6 duym in sijn borst. Den haan is I IO pondt swaer.

Den appel is wijdt $3^{1 / 2}$ voet en hoogh met de kroon 4 voeten, weegt 72 ponden.

't Kruys 750 pond
D'haen IIO,
D'appel $\frac{72}{932} \quad "$

Het staat wel niet vermeld, dat het zeer belangrijke werk, zonder tegenspoed, overeenkomstig de gestelde eischen en naar genoegen volvoerd werd, maar wij mogen veilig . besluiten, dat zulks het geval geweest is, juist, omdat wij niets bijzonders omtrent het 
verloop en den afloop der restauratie vermeld vonden. Neerlands Dichter, J. v. D. VONDEL, heeft, waar, naar het schijnt, ieder gezwegen heeft, het groote werk herdacht.

Hij [God] treft door 't Vier de Kroon van haaren schoonen Tooren, $\mathrm{Nu}$ heerelijk herbouwd en in den top voltoit.

\section{De Nachteg. van Amersfoort.}

De gelden, benoodigd tot goedmaking der kosten, alsook tot blijvend inkomen van de Kapel en den Toren, werden gevonden uit een belasting op de doodkisten. ${ }^{1}$ ) Van iedere doodkist, die door de timmerlieden werd afgeleverd, moest tot dat doel eenig geld gestort worden, dat, in cas van onwilligen, door den deurwaarder van het kwartier „bij paratc executic en tot kosten van de gebreeckigen” kon ingevorderd worden. Ziehier:

\section{Eyckenkisten."}

Dat den maecker van een groote eycken

Gid. overhoefde doodkist swart geverft sal genieten 9-1 -

Van een eycken kist als voorens, lang

5 voeten.................6- I -

Van een een eycken kist, als voorens,

lang 4 voeten................ $4-10$-.

Van een eycken ongeverfde overhoefde

grootc kist.................. 8 - -

Van een ongeverfde eycken doodkist

langh 5 voeten................4 4 - 10-

Item van eene langh 4 voeten..... 3-10-

Van een eycke platte ende groote doodkist. .

Van een van 5 voeten...........4 . -

Van cen langh 4 voeten.........2 2 - I5-

Vuyro kisten.

Van een overhoefde groote vuyre kist 4 - Jo-

Van een platte groote kist........ 4- .

Van een langh 5 voeten......... 2-15-

Van een langh 4 voeten of daaronder. I - IO -
Daerboven de Capelle sal genieten.

makende tsamen

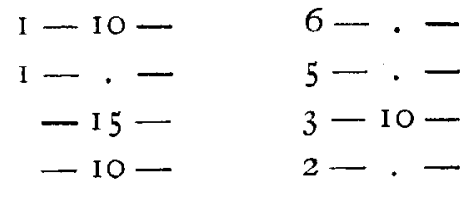

1) Resolutieb. I652, I2 Januari. De Regeerders resolveren in crachte deser, dat de timmerluyden nyet en sullen vermogen eenige dootkisten te leveren, anders als volgens schriftelijke ordre ende laste van een der Borgemeesteren, ofte in derselver absencie van den eersten Schepen, ende Raedt, met expressie van de namen voor wyen, de tijdt wanneer, ende qualiteyt van de persoon, ende dat voor cen groote doodkist in voegen voorseid gelevert, nyet meer gevalideert sal worden als een gulden thyen sts., ende voor een kleyne vijfthyen sts. ofte twaelf sts., naer proportie, de spijckers daer in gereeckent, die ten dien regarde tot laste van de stadt nyet geliaelt sullen mogen werden. 
In 1657,28 Sept. klaagden Nicasius Lenardtz en Peter Woutersen van LOCKHORST, stadstimmerluyden, er over, dat bun bij resolutie van I 2 Jan. I652, te weinig was toegelegd voor het maken en leveren van doodkisten voor arme luyden. Daarop werd den $29^{\text {sten }}$ Maart, 1658 , vastgesteld, dat een kist van 6 à 7 voeten lang, in plaats van I gld. ro sts., zal worden betaald met 2 gld.; een kist mincler dan 4 tot 5 voeten, zou gelden I gld. 5 sts.; mitsgaders voor de kleinste tot onder de vier voeten I5 sts., in plaets voor een kleyne vyftien of twaelff sts. naer proportie, de spyckers daerinne gerekent, die ten dien regarde tot laste van de stadt gehaelt noch gebracht sullen mogen worden. Gelijk men ziet, was het een zuinige tijd. Tot op de spijkers voor de doodkisten werd nauwkeurig acht gegeven.

Op den $6^{\text {den }}$ Mey 1726 klaagden de Regenten van de L. V. Kapel, dat de invordering van dat Reglement was genegligeert, en buiten usantie en effet gekomen, waarop door de Magistraat besloten werd, dat gemelde Resolutie van kracht soude blijven, en in dezer voege geampliëert worden:

\begin{tabular}{|c|c|c|}
\hline . & $\begin{array}{l}\text { Voor de maker } \\
\text { van de kist. }\end{array}$ & Voor de Kapel. \\
\hline van een groote overhoefde greene kist swart gevervt.. & $5-.-$ & $2-\cdot-$ \\
\hline 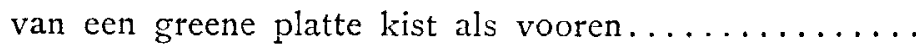 & $4-10-$ & $\mathrm{I}-\mathrm{IO}-$ \\
\hline van een greene kist als vooren groot 5 voeten....... & $3-5-$ & $I-5-$ \\
\hline van een langh 4 voeten $\ldots \ldots \ldots \ldots \ldots \ldots \ldots \ldots \ldots \ldots$ & $2-\cdot-$ & $I-.-$ \\
\hline $\begin{array}{r}\cdots \\
\text { of }\end{array}$ & $\begin{array}{l}15-.- \\
\text { I6- I- }\end{array}$ & nihil. \\
\hline
\end{tabular}

Deze prijsbepalingen werden op verschillende tijdstippen herhaaldelijk gewijzigd.

In 1657 , den $2^{\text {den }}$ Nov., werd een belangrijk besluit genomen. Door de "Heeren "Henrick van Ommeren, Rentmeester in de L. Vrouwe Capelle, Dor Henrick van "SCHAAK, dispensier aldaer, uyt crachte van speciale commissie van de Regenten der"selver Capelle, geassisteert met JAN MOM en Herrick VAN OUTERFF, mede-regenten "aldaar, en op approbatie derselver Regenten, mitsgaders van de Heeren Regeerders deser „stad ter eenre, en FRANÇOYS HEMONij ter andere zijde," werd een overeenkomst gesloten, waarbij HEMONI zich verbond te maken en "alhier ter Capelle te leveren op syn eygen „kosten, sonder buytenwerck, een nieuw klockspel, by hem opgegeven te wegen omtrent "ses duysent, twee hondert pont Amsterdamse gewichte, en dat soo suyver en van soo"danigen accorderende toon ende resonantie, datter geen ander beter speelwerck in dese ,Nederlanden sall worden bevonden, t'oordeelen en t'approberen bij onpartijdighe meesters "en musicyns, hun dies verstaende, ende bij de Regenten voornoemt daertoe te kiesen "en te assumeren." HEMONIJ zal mede gehouden zijn "den jegenwoordige groote clock, „aldaer mede t'synen costen, soo nae en soo goedt als doenlick is, mede op syn behoor"lyke toon, int selve speelwerck te brengen en te bequamen, mits dat hem tot het be- 
"quamen derselver Clock bij de Capelle sullen worden bij geboeckt, (lees: gevoegd) een timmerman en "smith tot hetselve werck noodig en vereyst."

Het werk zal binnen anderhalf jaar, "ten langesten van date deses" opgeleverd worden. Voor ieder pond klokspys, Amsterdamsch gewicht, door hem te leveren, zal HEMONIJ ontvangen achttien stuivers, mits hij daarentegen ieder „pont spys ter selver „gewichte der oude klokken en clockgespel in betaelinge en affslagh aenneemt tot tien „stuyvers.” Kwam .tijdens de leverantie der oude klockspijs de prijs hooger te staan, dan zou dat meerdere ten voordeele der Kapel strekken, en zal HEMONIJ gehouden zijn die tot dezelven meerderen prijs te nemen. De betaling zal geschieden in vier termijnen: een vierde bij het opnemen van het werk, een vierde een jaar daarna, een vierde wederom een jaar later, het laatste vierde gedeelte wederom een jaar later, zoodat de afbetaling plaats heeft binnen den tijd van drie jaren na de levering van het werk, zonder bijberekening van interest, behoudens een recognitie voor de huisvrouw van Hexonij en zijn knechts, ,tot discretie van de Heeren Regenten bij den eersten termijn "te furneren," enz.

Volgens v. Bemm., I. blz. 143, werd reeds in het volgend jaar 1658 het klokkenspel in den toren geplaatst.

Het speelwerk was echter niet geheel voltooid. Blijkens het Raadsbesluit van $166 \mathbf{I}$ $20 \mathrm{Mei}$, ,deficieerde eenige groote clocken ofte bassen, eer hetselve compleet was, waer ,toe het alreede gemaekte werck oock was aangelegt, waerdoor het geoordeelt soude worden "voor een van de frayste, heerlyclsste, harmonieuste en van de eelste resonantiie, dat by „FRANCOYS HeMONy gemaeckt soude syn.” Wijl echter , de Capelle alreede aent voor"seide werck merckelycke onkosten heeft gedaen en tyt van doen heeft van haer te ver"haelen" werd "geproiecteert" dat de stad voor den tijd "van zes of langer jaren de „interesse zoude betalen van de Capitaelen," die tot het laten vervaardigen van die klokken noodig waren.

HENRICK VAN OMMEREN werd diensvolgens door de Regeerders gemachtigd, om met Hemonij over de kosten van de verlangde klokken in onderhandeling te treden. Deze bracht den $5^{\text {den }}$ Aug. rapport uit. HEMONIJ had twee voorstellen in schrift gebracht. Ten einde een "compleet accoort van 't jegenwoordighe nye speelwerck" te verkrijgen, moesten de clocken vermeerderd worden met vier bassen, wegende 10,000 pond, het pond tegen I7 sts., te zamen gld. 8500-0-, met vermindering van "den als nu wesende "uyrklock tot omtrent 4000 pond à Io sts. per pond, dus gld. 2000-0-." Nog een ander voorstel werd door HEMONIJ gedaan, om namelijk „drye Bassen tot 6 IOO pond, het „pond als vooren, dus tot gld. 5185-0- onder aftrek van de uyrclock tot gld. 2000-0"te leveren." Er werd een commissie benoemd, om nader over die voorstellen te beraadslagen. Het duurde tot den $\sigma^{\text {den }} \mathrm{Julij}, \mathbf{I} 6 \sigma_{3}$, eer de zaak weer ter sprake kwam. Er werd medegedeeld, dat RUTGER EverTz, als rentmeester der Capel over het jaar i662, „bij zijn rekening gehoort en gesloten den $6^{\text {den }}$ Mei, 1663 ," een tekort had opgegeven van gl. 1993-8_6, 
„boven de renten van de alreede genegotiëerde capitaelen tot het opbouwen van Toorn, „koopen van nye klocken en Ton cum annexis, die de Capel dagelycx drucken en onder"houden."

Op het voorstel van Mr. JACOB VAN HORSEVOORT, organist en klockenist alhier, had Hemonij goedgevonden, dat de grootste klok in St. Joris-toren alhier voor de grootste bas zoude worden gebruikt, en onder den toon gebracht, en de tegenwoordige uurklok van de Kapel in de plaats worden overgebracht, „blijvende in restant de drye minder „bassen, wegende ses duysent, vyf hondert pond, het pond als vooren, makende vyff "duysent, vyf hondt, vyf en twintig gl. boven alle andere oncosten, die soodanighe wercken "nootsakelyck mede slepen." Na omvrage, hoofd voor hoofd gedaan, werd besloten het "speelwerk op de L. Vrouwen Toren te suppleren met vier bassen, daartoe gerequireert „doende ten dien einde de groote clock van St. Joris Kerck, en de uyrclock van de L. „Vrouwen Toorn weder aldaer, indien het geen belet aan 't geluy van St. Joris-Kerck "soude komen te veroorzaken." De Regenten van de L. Vrouwe Kerk werden gemachtigd de noodige gelden te negotiëeren, terwijl de Regeerders beloofden, gedurende den tijd van zes jaren, of totdat de Kapel in beter staat zoude gekomen zijn, de renten te zullen betalen.

Reeds den XXVIIsten Aug. werd dit besluit in dezer voege gewijzigd, dat besloten werd de klok in St. Joris te laten waar zij was, en ten spoedigste over te gaan tot het laten gieten van den vierden bas. De klokkegieter HEMONIJ en de horlogemaker SPRAEKEL hadden, toen Dor. HeNrick vas SCHAAK, Rentmeester, en HENRICK VAN OMmeren te Amsterdam waren gekomen, om de drie bassen in ontvangst te lemen, moeilijkheid gemaakt over het transporteeren van den klok uit St. Joris-kerk in de L. Vrouwe Kapel, en vice versa. Het gelui van St. Joris zou niet verbeteren, en na drie, vier jaren zou men toch wel besluiten, om een nieuwe klok te laten gieten. De stadstimmerman maakte insgelijks zwarigheid omtrent het doorzagen van eenige balken en andere verzwakkingen, die de toren zou ondergaan. Er werd daarom besloten, om ook den vierden bas of klok te laten maken.

Hiermede was de zaak nog niet afgeloopen.

Den I 2 den Oct. deelden de Regenten van de L. V. Kapel mede, dat de Borgers en Inwoonders inclinatie hadden tot "verblijf van de uyrclock in plaets van te versenden, "om versmolten te worden". Zij stelden daarom voor om gemelde klok te gebruiken tot een "luyklok, onder een recognitie van vier gld. boven het loon van treckers bij die "geene [te betalen], die gemelte clock sullen willen doen luyen, welverstaende, dat de "penningen, die de clock sal komen te renderen, te weten tegen Io sts. het pond, sall „komen en blijven tot laste van de capelle”. Dit voorstel werd aangenomen.

Zoo kwam de stad in bezit van een klokkespel, dat door kenners als zeer fraai en welluidend geroemd wordt. In onzen tijd bevinden zich daar 33 klokken, op welke met hoofdletters de volgende randschriften te lezen zijn: 
I Heelslagklok. + Zoo menigmael gij hoort den held'ren clockeslach, gedenk aendachtelijck aen uwen jongsten dach. H. VAN ScHAAK, rentmr. en H. VAN Ommeren dispens. deser Cappel. Anno 1663. Amersfoort.

2 Halfslagklok. + Dum campana sonor, properantem advertite mortem. FRANCiscus Hemony me fec. Amstellodami. A. I662.

3 + Grata est angelicis mea musica mixtca choraeis. F. Hemony me fecit, Amstellodami, anno domini I662.

$4+$ Dulcior e nostris resonat tinnitibus aër. Franciscus Hemony me fecit. Amstellodami. $A^{\circ} \mathbf{1} 662$.

5 + Laudabo nomen Dei cum cantico et magniftcabo eum in laude. F. Hemony me fecit anno domini 1659.

$6+$ Cantate Domino canticum novum id.

7 + Sit nomen Domini benedictum. id.

8 + Laudate Dominum in cymbalis benesonantibus. id.

9 A Anno Domini i659 Franciscus Hemony me fecit.

$10-26$

27 en 28

29 en 30 Anno Domini MDCLVIII fecit.

$" \quad " \quad$ MDCLIX fecit

99

,

3 I D. Grave Amsteldam 1725.

32 MELCHIOR (verder onleesbaar.)

33 Petrus ilemoni me fecit anno domini i 674.

De vier klokken, die het eerst genoemd worden, zijn blijkens het jaartal, de vier bassen, die in 1662 en 1663 aan het klokkespel werden toegevoegd. Bij besluit van de Magistraat den 5den Sept. I725 is de Kapel nog vereerd met drie klokjes, die an het geheel ontbraken, en den 3 den Octob. te Amsterdam gekocht werden. Aan den klokkenist HAN werd in het volgend jaar, I726, den 26sten Mei, voor diensten aan deze stad (waarschijnlijk bij gelegenheid van het aankoopen dier klokjes) bewezen, een geldelijke belooning van 52 gld. 18 sts. toegekend. Van de klok No. 3I is vermeld, dat zij in 1725 te Amsterdàm gegoten is. Misschien geldt zulks ook van No. 32. Een derde klokje uit dien tijd blijft onvermeld.

Uit het hierboven medegedeelde blijkt, dat er reeds in oude tijden in den $\mathrm{L}$. V. Toren luiklokken hebben gehangen. De kokergaten voor de touwen zijn nog aanwezig. Oọk schijnt de toren reeds vroegtijdig voorzien te zijn geweest van een uurwerk. In het Resolutieb., I60I, 6 Junij, leest men, dat de reparatie van het uurwerk in de L. V. Kapel wordt aanbesteed aan twee personen. Men zal toch hier het woord toren in plaats van kapel moeten lezen. Zulks blijkt daaruit, dat volgens VAN BEMM. I, 144, in dat jaar twee nieuzue borden en wijzers aan de Oost- en Westzijde geplaatst werden op de hoogte, waar men die tegenwoordig nog ziet. Er hebben dus reeds vroeger borden en wijzers 
gehangen. Misschien niet op dezelfde plaats. Volgens het Resolutieb., 1641, 16 Aug. ,verstaen de Regeerders, dat de Regenten van de L. V. Capelle metter eersten sullen "doen vermaecken 't uyrwerck van dezelve kerck en tselve mede augmenteren met twee "groote wijzers, te stellen op de ledige zijden neffens de wijsers-aldaer jegenwoordich "wesende, tot welck werck en in de costen van dien de stad deselve Capelle sal te gemoet commen". Die borden en wijzers werden geplaatst aan de Noord- en Zuidzijde.

Een nieuwe ramp trof den toren in 1683 . Op den 7 den Febr., juist op denzelfden dag, waarop ook voor 32 jaren zulks had plaats gehad, sloeg de bliksem weder in den toren. Reeds was de spits aangestoken en in brand, maar gelukkig werd het vuur in tijds gebluscht. Bartholemeus van Struyvenberg, in dat jaar Penningmeester van de L. Vrouwe Capelle, verhaalt, dat het vuur zoo hevig was, dat alle draden en andere werktuigen, noodig tot het klokkespel, gesmolten waren. In de volgende rijmregelen werd door STRUYvenBERG dit voorval vermeld:

God liet een donderslag secr vrecselijk ons hooren,

Die met een wolk vol vuyr neerborst op Kerk en Tooren

Ja stakse beyd' in brand tegen de swarte nagt,

Met een Noordwesten Storm, en 't hagelden met magt

Soo dat een yegelijk daar stond met schrik en beven

En dagt dit kost de stad en menig mensch sijn leven.

Maar Gods barmhartigheid door zijne sterke hand

Wend sijnen Toorn van ons Tooren die daar brand

En spaart de Kerk en Stad Miraculeus waaragtig

Och Zielen vreest den Heer, die groote God Almagtig,

Die door de wolken voert sijn Hemelsche Canon

En in een oogenblik het al vernielen kon.

Het duurde tot $\mathbf{I} 686$, eer men er toe overging, om de schade door den bliksem aangericht, te herstellen. Daar men van een restauratie echter niets vermeld vindt, schijnt de schade niet groot te zijn geweest. Gedurende geruimen tijd vindt men geen bijzonderheden omtrent den Toren vermeld. In de Novembermaand van I 787 werd, gelijk hierboven reeds gezegd is, de L. V. Kerk geheel en al vernield, zoodat zij voor het vervolg onbruikbaar was. Gelukkig bekwam de toren geen schade. Wel werden er herhaaldelijk pogingen aangewend om van de Provinciale Staten de noodige gelden tot wederopbouw te verkrijgen, maar deze haastten zich niet; de zaak werd op de lange baan geschoven, en raakte, onder de drukkende omstandigheden van het begin dezer eeuw, in het vergeetboek. Zonder dat iemand in verzet kwam, werd vermoedelijk omstreeks $\mathrm{I} 805 \mathrm{de} \mathrm{L} . \mathrm{V}$. Kapel voor afbraak verkocht.

In $\mathrm{I} 8 \mathrm{O} 2$ werd bij gelegenheid van het vredesverdrag tusschen Frankrijk en Engeland, de O. L. V. Toren op den $3^{\mathrm{I}^{\text {sten }}}$ Mei door middel van lantaarnen geillumineerd.

Inmiddels was de Toren in het jaar I803 op nieuw door den bliksem getroffen. De bliksem was op den derden omloop ingeslagen. Als mede-Regent van de L. V. Kapel stelde Mr. E. Methorst voor aan den Raad, om een bliksemafleider op den toren te plaatsen. 
In I804, 22 Feb., schijnt er brand in den toren te zijn geweest. Aan GERRIT DE Jong, ANDries Nisters en RYK CRUyF, die zich bij het blusschen verdienstelijk hadden gemaakt, werd met een gepaste aanspraak van den President een zilveren tabaksdoos vereerd. Op de doos stond het wapen van de stad gegraveerd. Wederom wordt er gedurende verscheiden jaren geen melding gemaakt van den Toren. Op den $4^{\text {den }}$ Julij i 854 nam de Raad het merkwaardig besluit, om tot afdoende restauratie over te gaan. Aan de stadsfabriek werd opgedragen, het doen herstellen van het kleine torentje, aan den derden omloop van den L. V. Toren. Bijna ieder jaar werd een gedeelte van den Toren, die er zeer vervallen uitzag, vernieuwd. De verweerde steenen werden uitgehakt, nieuwe steenen ingevoegd, terwijl de sieraden in den Gothischen stijl en zooveel mogelijk van Bentheimer steen vervaardigd werden. Verscheiden jaren duurden de werkzaamheden voort. In 1877 waren zij afgeloopen. Die restauratie was aan de gemeente op een som van meer dan gld. 26,000 te staan gekomen. In het Verslag van den toestand dér Gemeente over het jaar 1882 leest men, dat er binnen een paar jaren eenige herstellingswerken vereischt worden aan de lichte steenen tusschenpijlers tusschen den tweeden en derden omloop, welke thans door ijzeren staven en knelbanden bij elkander worden gehouden, doch waartusschen de steen geheel verweert en vergaat. Volgens het Verslag over het jaar I 886 verkeert de toren, over het algemeen, in voldoenden staat. Eerlang zal, voor zooveel betreft de tusschenpijlers en het à jour gedeelte, tot belangrijke vernieuwing moeten worden overgegaan, om te voorkomen, dat groote brokken steen uitvallen.

Amersfoort, $26 \mathrm{Mei}, \mathrm{I} 887$.

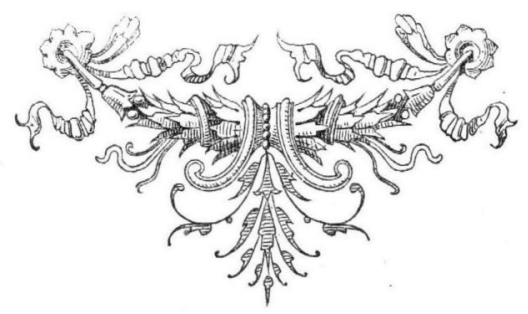

